\section{Peaceful and Happy Schools: How to Build Positive Learning Environments}

\author{
Şükran Calp*
}

\begin{tabular}{ll}
\hline Received: & 14 January 2020 \\
Revised: & 18 February 2020 \\
Accepted: & 22 March 2020 \\
ISSN: $1307-9298$ \\
Copyright (C) IEJEE \\
www.iejee.com
\end{tabular}

DOI: $10.26822 /$ iejee.2020459460

\title{
Abstract
}

It is very important for students and teachers to have a positive learning environment. The school that is an institution for educating children should be a peaceful and happy environment. There are principles such as love, respect, honesty, courage, empathy and kindness in the peaceful and happy schools. This study examined the concept of a "peaceful and happy school" and aimed to describe a peaceful and happy school from the point of view of primary school teachers and primary school students. It was designed with a case-study research model. A peaceful and happy school climate is the "case" of this study. The participants of the study consisted of 126 persons, 103 primary school students, and 23 primary school teachers from public schools in Turkey. Data were collected through face-to-face interviews from primary school students and teachers. Semi-structured interview form was used for both groups. At the end of the study, primary school teachers' and students' definitions of a peaceful and happy school were presented. It was understood from the findings that primary school students and teachers want to improve the same basic issues related to a peaceful and happy school.

Keywords: Peace, Happiness, Peaceful School, Happy School, Primary School

\section{Introduction}

The word peace is frequently used to mean the absence of war. However, this definition takes a severely narrow view of the word itself. It should mean not only the absence of war but also of violence in all its forms, such as conflict, poverty, injustice, discrimination, social degradation, pressure, and exploitation. It is a virtue, a disposition, an inclination towards helpfulness, trust, and justice. As long as violent social structures exist in society, peacebuilding will not be possible. In fact, peace expresses itself in three forms-peace with nature, social peace, and inner peace (Balasooriya, 2001) - and should thus serve to create an environment that fosters the human potential optimally.

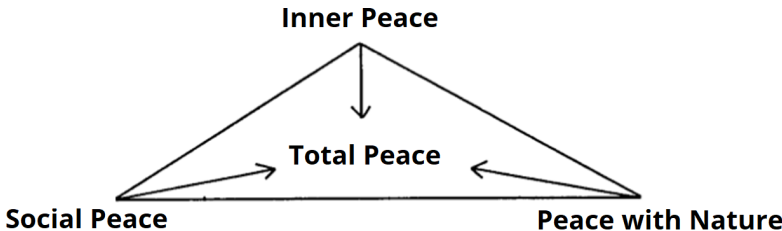

Figure 1. Sources of peace (Balasooriya, 2001)

Inner peace or peace of mind is peace with self. It is the state of harmony and peace with oneself and is associated with good health, absence of inner conflicts, feelings of kindness, compassion, serenity, bliss, happiness, contentment, joy, sense of freedom, insight, spiritual peace and satisfaction. It is the opposite of being stressed or anxious. Social peace is "learning to live together" and is the peace between man and man. For example, peace between people, conflict reconciliation and resolution, unity, friendship, brotherhood, love, acceptance, mutual understanding, cooperation, tolerance of differences, democracy, human rights, morality. Human beings are social beings; they can not live in isolation. And peace with nature implies stopping the violation of her dignity of through environmental degradation and exploitation. It refers to the harmony with natural environment and earth. Schools have a great responsibility to ensure inner peace, social peace and peace with nature. The importance of es- tablishing peaceful schools in society is obvious. Schools are the institutions where students gain academic knowledge and professional skills as well as social responsibilities, self-control and respect for other individuals. Every child has the right to education in a safe school environment (Leach, 2005). Education encourages independent thinking, and it provides opportunities for new ideas. Free thinkers, instead of blindly following the beliefs of others, tend to make sense of the world.

Peace is a concept that includes happiness. Happiness, health, social justice, good economy, freedom for expression and support for personal growth are elements of peace. The happy people are at peace with themselves; the people who are at peace with themselves are happy. Positive schools that can support peace are key to ensuring happiness, well-being, psyhchological health and achievement.

Happiness is not only the purpose of life but is also a state that can be achieved and taught through human effort. The school is one of the principal sources of human development and, as such, the basic place for facilitating happiness for children. A school where students, teachers, administrators, and staff feel happy may be defined as a happy school. A happy school is a place where everyone feels a sense of belonging to a community where they feel welcomed, satisfied, secure, and can be themselves. It is the collective responsibility of students, teachers, parents, and school administrators to create a loving and happy environment in school. It is also necessary to develop the school curriculum to make the school a happy place, that is, a place where students can feel the joy of learning.

It is important to start by educating children to create lasting peace. Education must prepare the children for effective participation in a free society, in a spirit of understanding, tolerance, equality of the sexes, and friendships among all peoples. In the classroom, students are often called upon to speak, read, present their opinions in small groups, or to work on projects together. This is how communication skills are refined. It should be noted here that communication is 
the key to resolving conflict. Therefore, students learn in the classroom to respect their teachers and their friends. They are taught to allow others to speak and express their opinions, how to deal with stress, and how to conduct themselves within a group setting.

If, in speaking about education, we say that "education is peace in other words", we won't be wrong. It can be said that the wisest way to build peace is to educate individuals first and then communities. Education shares knowledge, skills, values, and attitudes that are essential for the political, economic, and social development of countries. Peace education is the process that entails the acquisition of the values, the knowledge, and developing the attitudes, skills, and behaviors for a person to be able to live in harmony with themselves, with others, and with the environs (Salomon, 2002). According to Deutsch (1993), peace education is mainly a question of developing a skillset; the main purpose here is to cultivate a nonviolent disposition and acquire conflict resolution skills. Prime examples of such would be school-based, violence-prevention, peer-mediation, and conflict-resolution programs. Formulating a new discourse of peace in schools provides educators with a choice in respect of how they think, believe, and act in response to student wrongdoing and conflict (Cavanagh, 2009).

There are five elements that are necessary for building lasting peace through education. They are 1) an education system that advocates compulsory attendance for all children and youth, 2) a sense of mutual destiny that highlights mutual goals and a common identity, 3) teaching students the constructive controversy procedure, 4) training students in integrative negotiations and peer mediation to resolve their conflicts with each other constructively, and 5) inculcating values that focus students' attention on the long-term common good of society (Johnson \& Johnson, 2005).

In the world of education, there is an awareness that children should be taught the art of peaceful living. More and more concepts of peace, attitude, value, and behavioral skills are integrated into the school curriculum in many countries. There is also a growing interest in developing peace-related disciplines, such as value education, moral education, and global education. Peace education activities encourage knowledge, skills, and attitudes that assist with peaceful conflict prevention, resolve, or that create peaceful social conditions. Nonviolence and social justice values are crux peace education (Lubelska, 2018)

School climate is an important variable for a safe school environment. It refers to the quality and character of school life and includes the values, unwritten beliefs, and attitudes that become the style of interaction among students, teachers, and school administrators. The school climate determines acceptable behavior parameters among all school actors and assigns individual and institutional responsibility for school safety (Welsh, 2000). The school climate, defined as the quality of school relations, is a multidimensional concept that includes interpersonal, organizational, and instructional dimensions (Loukas, Suzuki, \& Horton, 2006). The school climate develops on the basis of common perceptions of people in the school, affects all people in the school, and is influenced by their behavior (Hoy, 2003). A peaceful school is a place that grows and sustains peaceful individuals, peaceful relationships, a peaceful school community, and peace work in the world.

A positive school climate is a vital component of successfu schools and is, therefore, often the purpose of school-wide initiatives (Brand, Felner, Shim, Seitsinger, \& Dumas, 2003; Koth Bradshaw, \& Leaf, 2008). Through the application of peace education and the creation of a peace culture, schools can possess important benefits. Some of these benefits are:

- Schools can develop a more humanistic administration approach.
- Schools can improve relationships between teacher and parent, teacher and student, teacher and teacher, student and student, and they can improve standard of quality of teaching and learning.

- Schools can develop good attitudes in students and teachers, such as, cooperation, mutual respect and they can improve students' moral behavior.

- Schools can help healthy emotional development in students.

- Schools can facilitate socialization through participation in interactive and cooperative learning activities.

- Schools can develop creativity of students and teachers (Balasooriya, 2001).

Education engenders confidence; confidence generates hope, and hope brings peace. Confidence has been defined as the belief that a person can succeed at something and hence the stimulation of a sense of self-confidence. Knowledge allows a person to feel a sense of accomplishment and become more courageous. It is a key confidence builder. This confidence or self-assuredness, in turn, sparks motivation and optimism, happiness, or the impetus to work towards peace. This study examined the concept of peaceful and happy schools as places where children are educated.

A great deal of research has been done on children's definition and perception of peace (Covell, Rose-Krasnor, \& Fletcher, 1994; Hakvoort \& Hagglund, 2001; Hakvoort \& Oppenheimer, 1993; Hakvoort \& Oppenheimer, 1998; McLernon \& Cairnes, 2001; Oppenheimer \& Kuipers, 2003). A considerable amount of research has been done on school climate (Banks, 2014; Brand, Felner, Shim, Seitsinger, \& Dumas, 2003; Cohen, McCabe, Michelli, \& Pickeral, 2009; Egeberg, McConney, \& Price, 2016; Gage, Prykanowski, \& Larson, 2014; Hernandez \& Seem, 2004; Koth, Bradshaw, \& Leaf, 2008; Thapa, Cohen, Guffey, Higgins-D'Alessandro, 2013; Turner, Reynolds, Lee, Subasic, \& Bromhead, 2014). In these studies, it was concluded that children can feel the concept of peace from an early age in relation to their cognitive development, and positive school climate predicted many variables, such as academic achievement, self-esteem, and well-being.

\section{Purpose of the Study}

This study examined the concept of a "peaceful and happy school" and aimed to describe a peaceful and happy school from the point of view of primary school teachers and primary school students. For this purpose, basically, two answers were sought:

\section{What is a peaceful and happy school like?}

2. What can be done to build a peaceful and happy school?

\section{Method}

\section{Research Paradigm}

The research was designed with a case-study research model-one of the qualitative research models. A peaceful and happy school climate is the "case" of present study, and it is discussed in the introduction. A case study is an intensive, holistic definition and analysis of a phenomenon or social unit (Merriam, 1988). According to Creswell (2007), it is a qualitative research approach in which the researcher examines one or more of the cases in-depth and defines the situations and themes. According to Yin (1994), a case study is an empirical research method that studies a current phenomenon in its real-life context. The purpose of a case study is to understand 
the process in detail, but this may include examining single or multiple cases and numerous levels of analysis. Although a case study has been defined in different ways, in-depth study and description of a situation is the common point of definitions. A case study is an important method of obtaining information because it provides rich and important perspectives about events and behaviors (Bloor \& Wood, 2006; Brown, 2008).

\section{Participants}

The participants of the study consisted of 126 persons, 103 primary school students, and 23 primary school teachers. The personal information of the students is as follows:

- Of all the students, 62 were girls and 41 were boys.

- The ages of the students varied between seven and ten and the average age was nine years.

- The students were selected from four different public schools in accordance with the official permits. The socio-economic level of the schools was largely similar and was identified as "intermediate" by the school administration. Student families were generally civil servants or workers.

- Academic achievement of students varied. Participants included students with low, intermediate, and high academic achievements.

The personal information of teachers is as follows:

- Of all the teachers, 14 were female and nine were male.

- The ages of the teachers varied between 29 and 54, with an average age of 39 years.

- Teachers worked in 4 different public schools and all were primary school teachers.

- The teachers' years of working in the profession varied between seven and 33 years.

\section{Data Collection Process}

Data for this research were collected through face-to-face interviews from primary school students and teachers. Permits were obtained from the Directorate of National Education to conduct interviews. A semi-structured interview form was used during the interviews. The interview form that was developed for recording students' views was also used as a teacher interview form. In particular, the same question was posed in different ways in case the students could not understand.

Appointments were made with teachers and the school administration to participate in the interview. Interviews with the students took place in each student's own classroom or in a suitable room of the school and lasted approximately 15 minutes. Interviews with teachers were conducted in the teachers' room and lasted approximately 15 minutes. The collected data were transcribed and prepared for analysis.

\section{Data Analysis}

The raw data obtained from the interviews were analyzed and interpreted using a "content analysis technique" (Yıldırım \& Şimşek, 2005). The first analyses were made and then an assigned faculty member rechecked the analyses. In case of disagreement, the related category was revised. Code names, such as "S1, S2, ..., S103" for students, and "T1,
$T 2, \ldots, T 23^{\prime \prime}$, for teachers were given in the order of the interviews. These code names were used when quoting the words of the students and teachers.

\section{Validity, Reliability and Credibility of the Study}

All studies are expected to provide a certain level of validity and reliability. Merriam (1998) proposed several strategies to obtain internal validity in case studies. These strategies include obtaining from colleague opinions about the findings (peer examination), data checking with the data source (member checks), the researcher's expressing their own views and thoughts at the beginning of the study (researcher's biases). For the internal validity of this study, the data were confirmed to the students and teachers. Additionally, opinions were obtained from an expert academician. For external validity, rich, thick description and typicality, or modal category techniques were used. Also, in order to increase the internal reliability and validity of the research findings, each step of the study was explained in detail and frequently quoted from the opinions of students and teachers. In order to ensure the credibility of the study, raw data were checked and confirmed by the teachers and students. The research report was also presented in detail to enable the reader to understand that the findings were safe.

\section{Findings}

Findings Related to the Primary School Students' Definition of Peaceful and Happy School

Primary school students were asked to give their definition of a peaceful and happy school. The answers from all 103 students were collected in 12 categories, as shown in Figure 2.

According to primary school students, these categories are: Fun place, a quiet place, a place where the teachers are not sad, a place with values, a place like home, a place where ideas are respected, a place without a fight, a place with rules, a place where games are allowed, a place where no one is scared of the teacher, a place where responsibilities are fulfilled and a decent and respectful place.

As Table 1 depicts, primary school students mostly used "fun" and "quiet" to describe a peaceful and happy school. The concept of fun took first place among the answers given when defining a peaceful school. The happiest place for them is where they have fun and the school gives them peace only when it is fun.

\section{S60: It's a fun place. It gives me pleasure.}

S73: A peaceful school is where I enjoy myself. Who can be peaceful or happy in a boring place?

Silence can sometimes be important and necessary for adults to feel at peace. But asking for silence in childhood is a situation that contradicts the developmental tasks of children. That is because, by nature, children learn not by silence but by communication, movement, and active action. They act aloud to understand as they explore the world. Therefore, the idea of silence is thought to be imposed by adults. The sentences of some of these students are as follows:

59: It is a quiet place where the teacher does not get upset.

S37: It's a quiet place where everyone is kind to each other.

Fifty-three students mentioned not to upset the teacher and not to bother him. According to them, the teacher should not be upset or annoyed. 


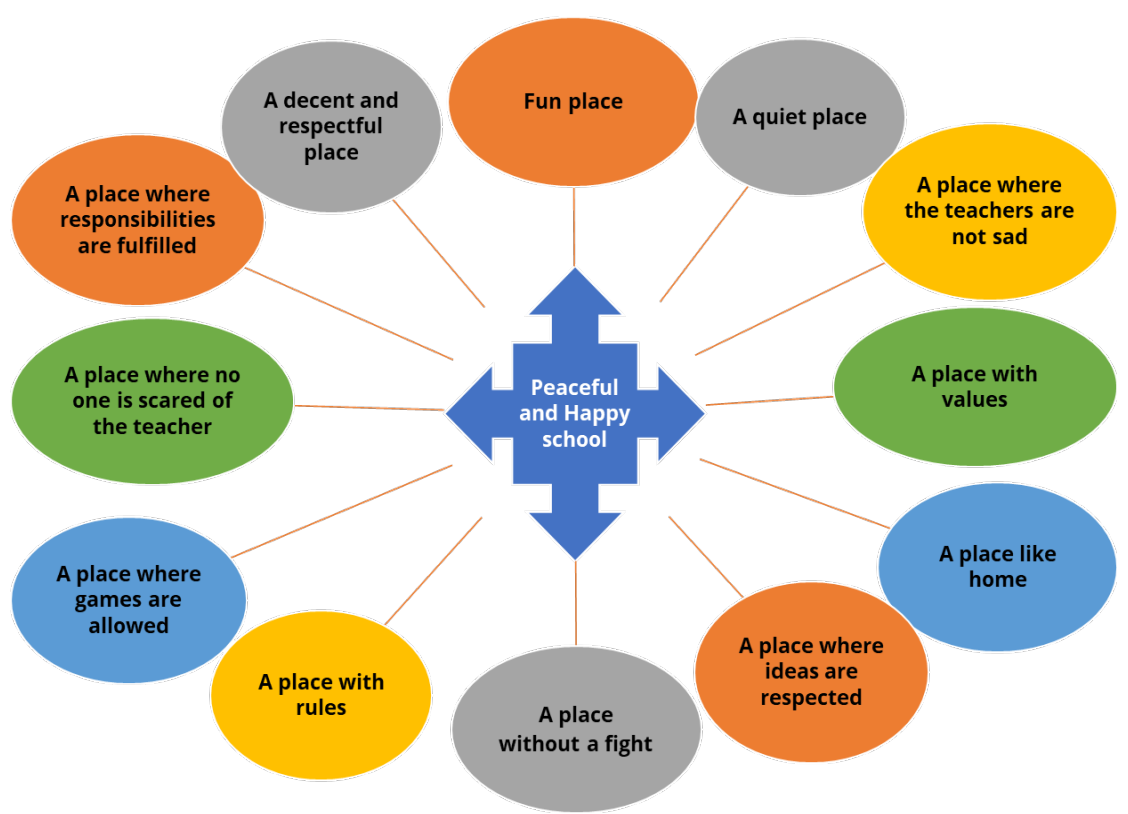

Figure 2. Primary school students' definition of a peaceful and happy school

Table 1. Codes used in definitions and students' frequency of making them

\begin{tabular}{|c|c|c|c|}
\hline & $\begin{array}{l}\text { What kind of place is a peaceful and } \\
\text { happy school? }\end{array}$ & Codes used by students & Frequency ( $f$ ) \\
\hline 1. & It's a fun place. & enjoyable, funny & 77 \\
\hline 2. & It's a quiet place. & noiseless, quiet & 65 \\
\hline 3. & It's a place where teachers aren't sad. & sad teacher, happy teacher, don't upset the teacher & 53 \\
\hline 4. & $\begin{array}{l}\text { It's a place where everyone is decent } \\
\text { and respectful. }\end{array}$ & sensitive, courteous, respect, deferent, regardful & 48 \\
\hline 5. & It's a place where there's no fighting. & have a fight, scuffle & 47 \\
\hline 6. & It's a place with rules. & $\begin{array}{l}\text { Avoid running on stairs, don't run in corridors, respect the principal, keep the rules, } \\
\text { damage class items, throw trash on floor, to use the school water without wasting }\end{array}$ & 45 \\
\hline 7. & $\begin{array}{l}\text { It's a place where no one is scared of } \\
\text { the teacher. }\end{array}$ & $\begin{array}{l}\text { fear of the teacher, scared of the teacher, afraid of the teacher, yelling teacher, } \\
\text { shouting teacher, violence }\end{array}$ & 44 \\
\hline 8. & It's a place where games are allowed. & playing field, playground, outdoor playing & 40 \\
\hline 9. & It's a place like home. & a place with a kitchen, home comfort, feel comfortable, feel relaxed & 32 \\
\hline 10. & $\begin{array}{l}\text { It's a place where responsibilities are } \\
\text { fulfilled. }\end{array}$ & prepare a school bag, listening to the lesson, speak by permission, do homework & 29 \\
\hline 12 & It's a place with values. & Honesty, love, respect, honesty, helpfulness, sharing, compassion, kindness & 28 \\
\hline 12. & It's a place where ideas are respected. & respect for different thoughts, respect for thoughts & 22 \\
\hline 13 & It's a place where everyone is happy. & inner happiness & 1 \\
\hline
\end{tabular}

S100: Students should be in class when the break is over and should not make any noise. Otherwise, the teacher is upset. We must not annoy the teacher.

S97: In peaceful schools, teachers are not sad and frustrated. Forty-eight students talked about being respectful and decent. A peaceful school is a place where respect is important to them.

S23: It is a place where everyone is respectful.

S88: Decent students are in peaceful schools. A peaceful school is a place with mostly decent students.

Forty-seven students defined a peaceful school as a place where there is no fighting or bullying. Forty-five students emphasized the importance of school rules for a peaceful school. It is thought that the ideas of following the rules or creating rules together are two subjects that teachers frequently impose on the students. Children are aware that they must follow the rules and this is a positive attitude. But it is an incomplete learning that the child think only rules must be followed for peace and happiness. Below are excerpts from those students' own words.
S25: It is a place where there is no fighting. Nobody should disrespect each other.

S8: A peaceful school is a place where there is no lie, and people don't shout loudly at each other.

S103: Students should enter the class when the break is over. He can talk to his friend for 2-3 minutes. He must not run or shout in the corridors of the school.

It can be interpreted that forty-four students are unhappy because of the hard attitude of the teacher. This is seen from their definition of a peaceful school as a place where teachers are not angry, shouting, or calling violence. Below are excerpts from the responses of those students.

\section{S6: It is a place where we are not afraid of the teacher.}

S79: This is where the teacher does not beat or hit hard.

S101: In such schools, teachers do not get angry or shout. I'm very afraid of such a teacher. I feel at peace when the teachers are not rude to us. 


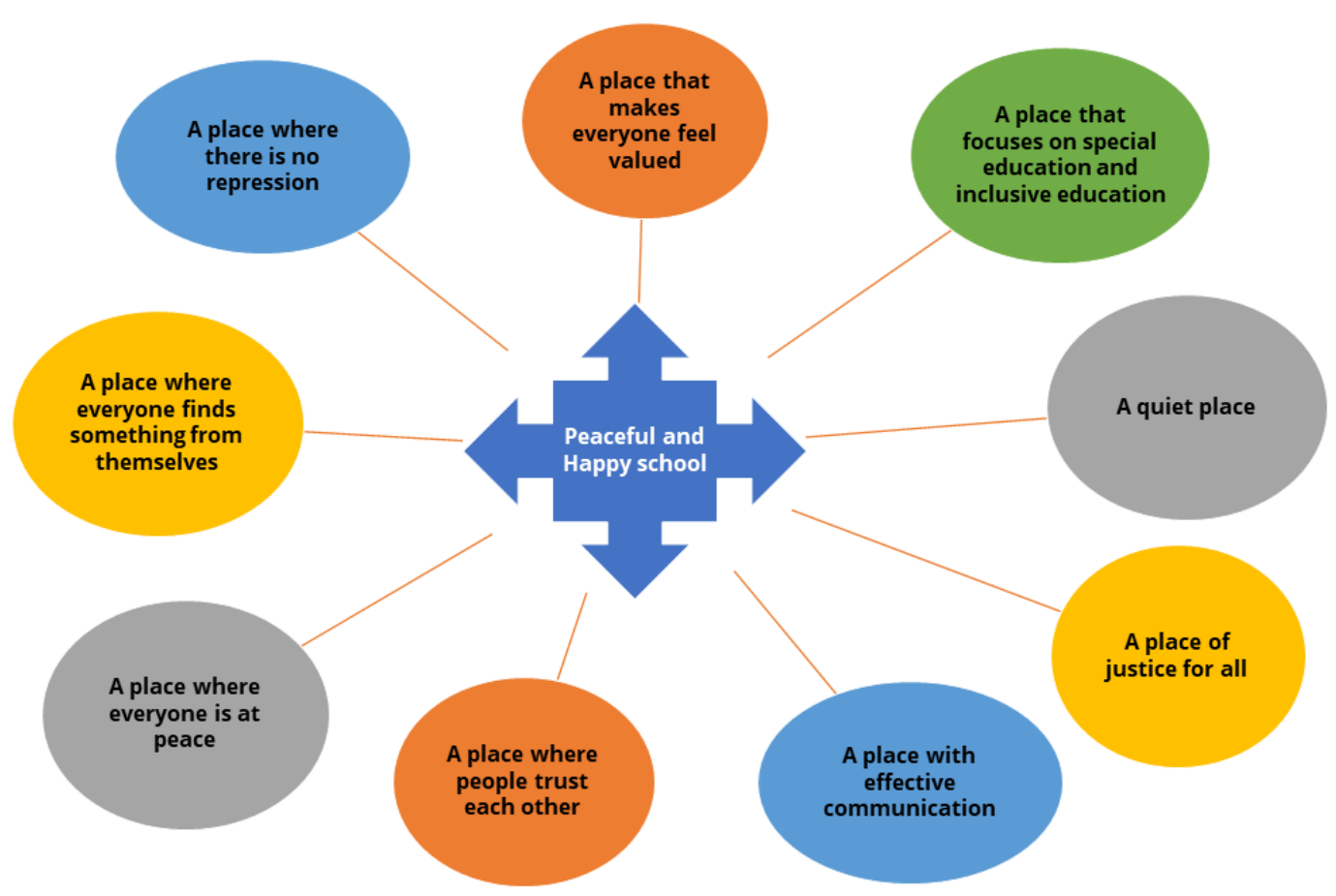

Figure 3. Primary school teachers' definition of a peaceful and happy school

Some students consider games as an important tool for peace. According to them, they would be very happy if they were allowed to play more games. Happy children are in peaceful schools. These children also want to increase the number of playgrounds in their schools because, according to them, peace is playing games.

Thirty-two students want to feel at home while at school. For example, there are students who think that if a school has a kitchen, it would make them very happy. There are some students who say that they would be happy to see their favorite toys, books, and personal belongings like family photos at school.

\section{S99: I have to be as comfortable as in my house. At peace, that's it. \\ S1: Every place that looks like my home is peaceful. I am happy everywhere that looks like my room.}

Some students talked about fulfilling responsibilities; some talked about values, such as love, helpfulness, solidarity, empathy, and others talked about respecting different ide- as. It is an important finding that respecting thoughts or different thoughts is valuable for a child and seen as the key to peace. Students' perceptions that universal values will ensure peace are also very important. Below are direct excerpts from the students' sentences.

S10: A peaceful and happy school, love, respect, honesty, helpfulness, sharing, compassion, in short, with good morality.

S3: A peaceful class is like this: Everyone respects the opinions of others. Students listen carefully to what the teacher tells.

S61: It is a place of good people. It is a place where ideas are respected.

One of the most remarkable answers among 103 students is the answer of the student with code name S11. S11 draws attention to inner happiness. He thinks that school will be peaceful if people feel happy. Moreover, he believes that the school will feel this happiness.

511: If everyone is happy in the school, the school will be peaceful and happy. School feels like a human. Because everyone smiles.

Table 2. Codes used in definitions and the teachers' frequency of making them

\begin{tabular}{|c|c|c|c|}
\hline & What kind of place is a peaceful and happy school? & Codes used & Frequency (f) \\
\hline 1. & It's a place where makes everyone feels valued. & appreciation, value, precious & 23 \\
\hline 2. & It's a place where there is no repression. & violence, pressure someone & 17 \\
\hline 3. & $\begin{array}{l}\text { It's a place where everyone finds something from } \\
\text { themselves. }\end{array}$ & special items, favorite items, pleasures & 14 \\
\hline 4. & It's a place of justice for all. & equality, equal rights, discrimination & 13 \\
\hline 5. & It's a place where people trust each other. & $\begin{array}{l}\text { trust each other, do something behind someone's back, } \\
\text { confidence, put one's trust in, take on trust }\end{array}$ & 10 \\
\hline 6. & $\begin{array}{l}\text { It's a place where everyone is at peace with them- } \\
\text { selves. }\end{array}$ & everyone is at peace, inner peace & 9 \\
\hline 7. & It is a place with effective communication. & $\begin{array}{l}\text { good communication, dialog, cooperation with parents, } \\
\text { dialog with teacher }\end{array}$ & 9 \\
\hline 8. & It's a quiet place. & calm, tranquil, restful, noiseless, quiet, hushed & 4 \\
\hline 9. & $\begin{array}{l}\text { It's a place that focuses on special education and } \\
\text { inclusive education. }\end{array}$ & $\begin{array}{l}\text { special education, inclusive education, disabled people, } \\
\text { autism, individual difference }\end{array}$ & 2 \\
\hline
\end{tabular}


Table 3. Suggestions of teachers for a peaceful and happy school

Suggestions of Teachers

1. Suggestions for "self"

Teachers should be made to feel happy.

Teachers' self-esteem and self-confidence should be increased.

Teachers should be made to feel valuable.

A class identity must be created for each student.

2. Suggestions for values

The teacher should treat the students fairly and the school principal should treat the teachers fairly.

The importance of values, such as tolerance, respect, and love, should be emphasized.

Universal values should be taught.

3. Suggestions for the physical characteristics of the school

School should not be a boring place; it should be transformed into a relaxing place.

The physical conditions of the school should be improved.

The school environment should be arranged like a home environment.

A variety of activity rooms should be created to address the interests of everyone in the school.

Schools should be turned into campuses with many social facilities.

4. Suggestions for relationships

A communication similar to the family's communication with the child should be between the student and the teacher.

Cooperation with parents should be made.

Teachers should establish good relations with each other.

Trainings should be provided to build trust among people.

5. Suggestions for learning and teaching

Fun activities for teachers should also be organized.

Specific or individualized conditions should be created for each child.

Students should enjoy learning.

6. Suggestions for unwanted behavior

Seminars on bullying should be organized.

Strategies should be developed to prevent school violence.

7. Suggestions on the Ministry of National Education and school administration

School principals should change frequently.

Excursion activities organized at school should be increased.

The school management should receive regular opinions and suggestions from the students and determine their needs.

Teachers who are professionally equipped should be hired.

Findings Related to the Primary School Teachers' Definition of a Peaceful and Happy School

Thirteen teachers mentioned that people should trust each other. According to them, peace can only occur when people trust each other.

Primary school teachers were also asked to define a peaceful and happy school. The answers were collected in nine categories as shown in Figure 3.

According to primary school teachers, these categories are: A quiet place, a place that makes everyone feel valued, a place that focuses on special education and inclusive education, a place of justice for all, a place where people trust each other, a place where everyone is at peace, a place where everyone finds something from themselves, a place where there is no repression.

As Table 2 indicates, the teachers mostly emphasized that everyone felt valuable when defining this school. All of the teachers want to see value and the place where they feel they are valuable is peaceful and happy for them. According to seventeen teachers, a peaceful place is a place where there is no pressure, bullying, or violence. Fourteen teachers want to feel at home, to see their personal belongings, their favorite dessert. The last book they read at school puts them more at peace. Some teachers $(f: 13)$ want a fair world for all. The place where the value of justice is felt is peaceful for them.

Nine of the twenty-three teachers mentioned internal peace. People must first be at peace with themselves, according to them. The place where individuals are at peace with themselves is peaceful. Some teachers ( $f: 9)$ mentioned the importance of communication and stated that they believe that quality communication brings peace. The emphasis on silence or tranquility is important for peace among teachers as well as for primary school students. Four teachers stated that they thought that a quiet place was peaceful. Two of them believe that a place where people with disabilities are cared for is peaceful. Individual differences should be considered. Below are the responses of some of the twenty-three teachers.

T1: Feeling precious, very nice. One can only find peace in a place where one feels one is valuable. One is at peace, where people trust each other. One is peaceful where there is no repression and bullying. For me, there is no peaceful place. There are peaceful people.

T6: I want to trust the people around me. Everyone should believe in each other. Everyone should be honest. There should be no lies in relationships. Such a place is peaceful. 
Table 4. Suggestions of students for a peaceful and happy school

\begin{tabular}{|c|c|c|}
\hline & Suggestions of Students & Frequency (f) \\
\hline \multirow[t]{5}{*}{1.} & Suggestions for the physical characteristics of the school & 67 \\
\hline & Playgrounds should be established in the school. & \\
\hline & The school should be fun, not boring. & \\
\hline & The school environment should be arranged like a home environment. & \\
\hline & The most popular personal belongings should be brought to the school and placed in a suitable place in the classroom. & \\
\hline \multirow[t]{3}{*}{2.} & Suggestions for unwanted behavior & 59 \\
\hline & Students should not hit each other. & \\
\hline & Nobody should swear. & \\
\hline \multirow[t]{2}{*}{3.} & Suggestions for values & 56 \\
\hline & Everyone should respect each other. & \\
\hline \multirow[t]{2}{*}{4.} & Suggestions for learning and teaching & 51 \\
\hline & Lessons should be fun. & \\
\hline \multirow[t]{7}{*}{5.} & Suggestions for contact & 48 \\
\hline & Teachers should be good friends with each other. & \\
\hline & Everyone should have good friends. & \\
\hline & Even if people think differently, there must be unity. & \\
\hline & The headmaster should not shout at the students. & \\
\hline & Teachers should not be angry with students. & \\
\hline & People should not be angry and rude to each other. & \\
\hline 6. & Suggestions for rules & 45 \\
\hline
\end{tabular}

6. Suggestions for rules

While the Turkish Independence Anthem is sung, no one should move.

Students should not throw trash to the floor. When they meet the headmaster, they must stop and wait and show respect for him.

7. Suggestions for reward

The school should give gifts to students for their good behavior.

The school headmaster should give a surprise prize to the smartest student of every day.

T17: There should be no violence, no pressure, no threat. I should do a thing just because I want to. I should to enjoy what I do. The key is to eliminate psychological violence and bullying.

T23: The place can be peaceful if parents manage to have good relations with teachers, teachers with teachers, and teachers with students

Findings on the Suggestions of Students and Teachers for a Peaceful and Happy School

Primary school students and teachers were asked what they recommended for a peaceful and happy school. These suggestions are included in Tables 3 and 4.

As Table 3 shows, teachers mostly focused on the concept of self. Twenty-three teachers talked about self-esteem, creating an identity, and feeling valuable. According to these teachers, it is important to create a class identity for the students. There are twenty-one teachers who drew attention to the importance of universal values, such as tolerance, respect, love, and justice. Some teachers mentioned that the physical characteristics of the school should be improved. Fifteen teachers' suggestions were to ensure effective communication. Nine teachers proposed to transform learning into a fun form for peaceful schooling. Some teachers talked about the need to prevent bullying and violence, while others made suggestions to government officials.

As Table 3 shows, teachers mostly focused on the concept of self. Twenty-three teachers talked about self-esteem, creating an identity, and feeling valuable. According to these teachers, it is important to create a class identity for the students. There are twenty-one teachers who drew attention to the importance of universal values, such as tolerance, respect, love, and justice. Some teachers mentioned that the physical characteristics of the school should be improved. Fifteen teachers' suggestions were to ensure effective communication. Nine teachers proposed to transform learning into a fun form for peaceful schooling. Some teachers talked about the need to prevent bullying and violence, while others made suggestions to government officials.

As Table 4 shows, students mostly focused on the physical characteristics of the school. Children want to increase the number of playgrounds to feel at peace. In addition, some students said that they wanted to feel as comfortable at home as they were at school. Thus, they suggested that the school be compared to the home environment. Students who think that unwanted behaviors should be prevented suggest a school where there is no violence (f: 59). Fifty-six primary school students mentioned that everyone should be respectful to each other. Fifty-one students suggested that the lessons should be fun for peaceful schools. Forty-eight of the students made suggestions regarding communication. Particularly, the recommendations of the student code-named S57 are remarkable: He explained that the teachers in a happy school should have good relations with each other. He also stated that the children felt this relationship and evoked negative feelings towards the students with whom the teacher disagreed or disliked in the other teacher's class. Forty-five students who believe that the rules should be followed think this is essential for peaceful schools. Twelve students wanted to be rewarded. According to them, the source of a peaceful school is rewards.

\section{Discussion and Conclusion}

It is understood from the findings that primary school students and teachers want to improve the same basic issues related to a peaceful and happy school. As Figure 4 shows 


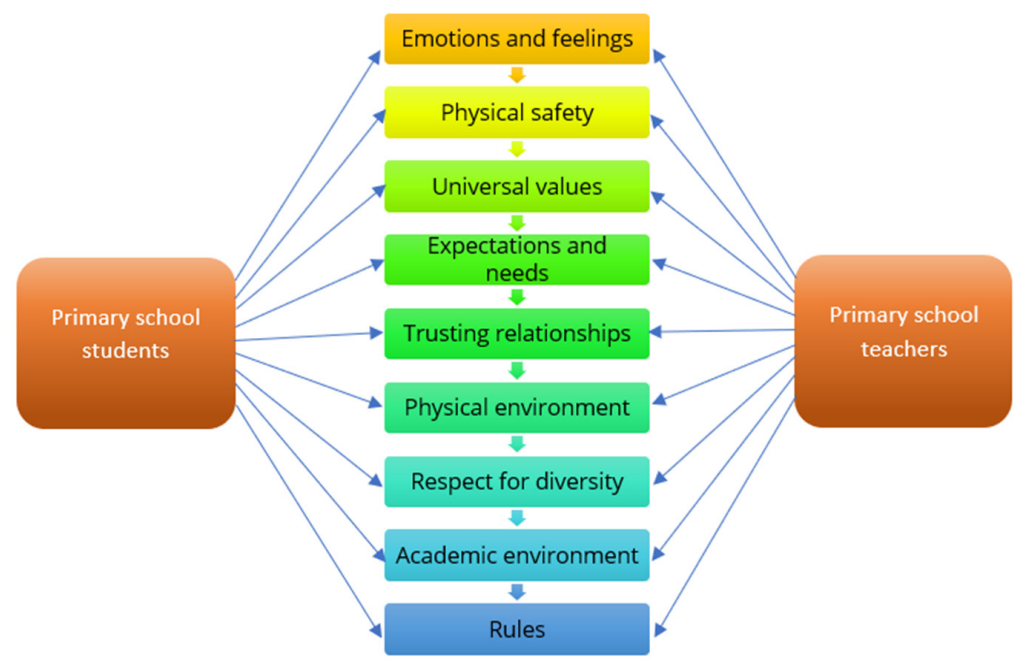

Figure 4. Concept of a peaceful and happy school according to primary school teachers and students

that emotions and feelings are important for both groups. Both students and teachers need to feel valued. Teachers have also dreamed of a school where everyone feels happy.

According to the findings of this study, the issue of physical safety is also an issue to be considered. Children do not want teachers or classmates to use physical violence against them. Teachers desire a school without violence and bullying. Bully students scare other students with their words and actions. Bullies rob others of their right to free learning, making other children feel unsafe and often causing them to be absent from school (Olweus, 2002; Olweus, 2003). Students who are exposed to bullying have various problems. It was found that students who were bullied (victim) had feelings of anxiety, anger, and helplessness; it is claimed that bullying can be a reason for not wanting to be in school or even attempting suicide. Furthermore, it has been revealed that as the absenteeism of the students who have been bullied increases, their self-esteem decreases (Elliot, 1992).

Universal values are very important for peaceful and happy schools. It is not possible to build a peaceful school without love, respect, and tolerance. Teachers and students alike have some expectations and needs. The most basic need for teachers is to feel valued. Students want a fun-filled school environment.

Relationships are the source of peace for both groups. Children want to establish good relations with their peers, and moreover, they want to make good friends. Teachers want to have good relations with other teachers, parents, and school administrators. According to the teachers, it is very important that people trust each other. Similarly, in a study by Slaughter-Defoe and Carlson (1996), children viewed teacher-child relations as the most important dimension of school climate. Children also stressed teacher fairness, caring, and praise for effort as well as the importance of moral order, values, following school rules, and performing well.

Some children related peace to "unity among people" (Oppenheimer \& Kuipers, 2003). Hakvoort (1996) emphasized the importance of positive social themes involving friendship and care for others for a true understanding of positive peace. According to a study by Koth, Bradshaw, and Leaf (2008), school size, characteristics of the teacher, class size, and the concentration of students with behavior problems are significant predictors of perception of a positive school climate. These findings suggest that features of the classroom environment are important to consider when purposing to improve school climate.
According to the findings of the present study, teachers and students suggest that the physical school environment should be reorganized to make them feel more comfortable. Both groups want to feel as if they are in their own home while at school. Children think that there is a need for big playgrounds for a peaceful and happy school. Boredom or having nothing to do can be the cause for undesirable behaviors, but the children happily involved in play reflect an engaging environment and support a peaceful environment (Levin, 2003).

Teachers and students alike think that respect for differences and different ideas is an important element of a peaceful school. People may just look different and think differently.

According to teachers and primary school students, the academic environment is critical for creating peaceful and happy schools. A positive academic climate is the key to peace. Children desire fun lessons. Teachers propose individualized teaching programs. According to teachers, students should enjoy learning. Another important positive school-climate-related dimension is rules and norms. According to the findings, obeying the rules is necessary for a peaceful and happy school. In the school environment, each individual has duties and responsibilities. There are also some rules for living together. Problems arise when these rules are violated. Some researchs underscore the importance of school rules in regard to dealing with students' undesirable behavior (Gottfredson, Gottfredson, Payne, \& Gottfredson, 2005; Halstead, \& Taylor, 2000; Malone, \& Tietjens, 2000; McGinnis, Frederick, \& Edwards, 1995).

There are many studies in the literature supporting the results of this study. It was determined that variables, such as teacher support, participation in classroom activities and decisions, peer relations, defined rules, physical conditions of class and school, which are the characteristics of positive school climate, were related to the academic achievements of students and teachers (Brand, Felner, Shim, Seitsinger, \& Dumas, 2003). Lower levels of violence are observed in schools where students are involved in decision-making, where rules are clear, consistent, and impartial, and where students are respected (Olweus, 2003). Welsh (2000) concluded that the three school climate variables were inversely related to bullying behavior and victimization. These variables are respect for students, student participation, and clarity of school rules.

According to Bandura's social learning theory, bullying behaviors are formed by the interaction of individual and environmental factors, and therefore, the social environment has direct and indirect effects on the formation of bullying. Direct 
effect: Children learn the aggressive behavior model from their peers and adults. Indirect effect: Children receive and accept perceptions, norms, and trends (Natvig, Albrektsen, \& Qvarnstrom, 2001)

\section{Suggestions}

According to the results of this research, the following are recommended for peaceful and happy schools:

For effective relationships, trust should be built. Friendship and a good relationship between students and teachers as well as between teachers and teachers should be ensured.

It should be felt that everyone's feelings and thoughts are valuable.

Measures should be taken to eliminate physical and psychological violence at school.

Students should first be directed to work for their inner peace and happiness. They should be made to feel that inner peace will make the school peaceful.

Students should be made aware that peace can only be built in collaboration.

It is very important to develop a sense of belonging to the school. So, the physical conditions of the school should be improved. Students and teachers should feel at home.

School should not be a boring environment. For this, everyone in the school must act together; expectations and needs should be fulfilled.

Children are happy in a school where they learn and play. In order for future generations to contribute to a more peaceful world, all students should feel happy.

Courses should be engaging and fun for students, and courses should have creative and colorful instructional materials and fun activities. In addition, students should enjoy learning.

Teachers should be informed about alternative ways or programs on how to build peaceful and happy schools

\section{References}

Balasooriya, A. S. (2001). UNESCO Office New Delhi and Regional Bureau for Communication and Information in Asia and the Pacific. learning the way of peace: $A$ teachers' guide to peace education. United Nations Educational, Scientific and Cultural Organization, New Delhi. Retrieved from http://unesdoc.unesco.org/ images/0012/001252/125228eo.pdf

Banks, T. (2014). Creating Positive Learning Environments: Antecedent Strategies for Managing the Classroom Environment \& Student Behavior. Creative Education, $5,519-524$

Bloor, M., \& Wood, F. (2006). Keywords in qualitative methods: A vocabulary of research concepts. London: Sage Publications. https://cstn.files.wordpress.com/2009/10/ keywords-in-qualitative-methods.pdf

Brand, S., Felner, R., Shim, M., Seitsinger, A., \& Dumas, T. (2003) Middle school improvement and reform: Development and validation of a school-level assessment of climate, cultural pluralism, and school safety. Journal of Educational Psychology, 95(3), 570-588.
Brown. A. P. (2008). A review of the literature on case study research. Canadian Journal for New Scholars in Education, 1(1), 1-13.

Cavanagh, T. (2009). Creating a new discourse of peace in schools: Restorative justice in education. Journal for Peace and Justice Studies, special issue on Restorative Justice, 18(1-2), 62-84.

Cohen, J., McCabe, E. M., Michelli, N. M., \& Pickeral, T. (2009). School Climate: Research, Policy, Teacher Education and Practice. Teachers College Record, 111, 180-213.

Covell, K., Rose-Krasnor. L., \& Fletcher, K. (1994). Age differences in understanding peace, war, and conflict resolution. International Journal of Behavioral Development, 17, 717-737.

Creswell J. W. (2007). Qualitative inquiry and research design; choosing among five approaches. Thousand Oaks: Sage.

Deutsch, M. (1993). Educating for a peaceful world. American Psychologist, 48, 510-517.

Egeberg, H. M., McConney, A., \& Price, A. (2016). Classroom Management and National Professional Standards for Teachers: A Review of the Literature on Theory and Practice. Australian Journal of Teacher Education, 41(7): 1-19.

Elliot, M. (1992). Bullying. A Practicical Guide to Coping for Schools. Wiltshire: Longman.

Gage, N. A., Prykanowski, D. A., \& Larson, A. (2014). School climate and bullying victimization: A latent class growth model analysis. School Psychology Quarterly, 29(3), 256-271.

Gottfredson, G. D., Gottfredson, D. C., Payne, A., \& Gottfredson, N. C. (2005). School climate predictors of school disorder: Results from national delinquency prevention in school. Journal of Research in Crime and Delinquency, 42, 421-444.

Hakvoort, I. (1996). Conceptualizations of Peace and War from Childhood Through Adolescence. Unpublished doctoral dissertation, University of Amsterdam, Amsterdam, Netherlands.

Hakvoort, I., \& Hagglund, S. (2001). Concepts of peace and war as described by Dutch and Swedish girls and boys. Peace and Conflict: Journal of Peace Psychology, $7(1), 29-44$.

Hakvoort, I., \& Oppenheimer, L. (1993). Children and adolescents' conceptions of peace, war, and strategies to attain peace: a Dutch case study. Journal of Peace Research, 30, 99-119.

Hakvoort, I., \& Oppenheimer, L. (1998). Understanding peace and war: a review of developmental psychology research. Developmental Review, 18, 353-389.

Halstead, J.M., \& Taylor, M.J. 2000. Learning and teaching about values: A review of recent research. Cambridge Journal of Education, 30, 169-202.

Hernandez, T. J., \& Seem, S. R. (2004). A safe school climate: A systematic approach and school counselor. Professional School Counseling, 7, 256- 262

Hoy, W. K. (2003). School Climate. In J.W. Guhtrie (Ed.), Encylopedia of education (2nd ed.), (pp. 2121-2124). New York: Thompson Gale. 
Johnson, D. W., \& Johnson, R. (2005). Essential components of peace education. Theory into Practice, 44(4), 280-292. https://doi.org/10.1207/s15430421tip4404_2

Koth, C. W., Bradshaw, C. P., \& Leaf, P. J. (2008). A multilevel study of predictors of student perceptions of school climate: The effect of classroom-level factors. Journal of Educational Psychology, 100(1), 96-104.

Leach F. (2005). Learning to be violent; The role of the school in developing adolescent gendered behavior. Compare, 33(3), 385-400

Levin, D. E. (2003). Teaching Young Children in Violent Times: Building a Peaceable Classroom, second edition. Washington, DC: co-published by NAEYC and Educators for Social Responsibility.

Loukas, A., Suzuki, R., \& Horton, K. D. (2006) Examining schoo connecyedness as a mediator of school climate effects. Journal of Research on Adolesence, 16(3), 491-502.

Lubelska, A. (Edt) (2018). How to be A Peaceful School, Practical Ideas Stories and Inspiration. London: Jessica Kingsley Publishers

Malone, B.G., \& Tietjens, C.L. 2000. Re-examination of classroom rules: The need for clarity and specified behaviour. Special Services in the Schools, 16(1-2), 159-70.

McGinnis, J. C., Frederick, B. P., \& Edwards, R. 1995. Enhancing classroom management through proactive rules and procedures. Psychology in the Schools, 32, 220-24.

McLernon, F., \& Cairns, B. (2001). Impact of political violence on images of war and peace in the drawings of primary school children. Peace and Conflict: Journal of Peace Psychology, 7(1), 45-57.

Merriam, S. B. (1988). Case Study Research in Education: A Qualitative Approach. JosseyBass, San Francisco.

Natvig, K. G., Albrektsen, G., \& Qvarnstrom, U. (2001). Psychosomatic symptoms among victims of school bullying Journal of Health Psychology, 6(4), 365-77.

Olweus, D. (2002). Annotation: Bullying at school: Basic fact and effects of a school basit intervention program. Journa of Child Psychology and Psychiatry, 35(7), 1171-1190.

Olweus, D. (2003). A profile of bullying at school. Educational Leadership, 60(6). https://www.researchgate.net/publication/279570438_A_profile_of_bullying_at_school

Oppenheimer, L., \& Kuipers, I. (2003). Filipino children's understanding of peace, war, and strategies to attain peace. Peace and Conflict: Journal of Peace Psychology, 8, 235 257.

Salomon, G. (2002). The nature of peace education: Not all programs are created equal. In: G. Salomon and B. Nevo (Eds.). Peace Education, The Concept, Principles, and Practices Around the World (pp. 2-14). Mahwah, NJ: Lawrence Erlbaum Associates Publishers.

Slaughter-Defoe, D. T., \& Carlson, K. (1996). Young African American and Latino children in high-poverty urban schools: How they perceive school climate. Journal of Negro Education, 65, 60-70.

Thapa A., Cohen J., Guffey S., \& Higgins-D'Alessandro A. (2013). A review of school climate research. Review of Educational Research, 83(3), 357-385.
Turner, I., Reynolds, K. J., Lee, E., Subasic, E., \& Bromhead, D. (2014). Well-being, school climate, and the social identity process: A latent growth model study of bullying perpetration and peer victimization. School Psychology Quarterly, 29(3), 320-335.

Welsh, W. N. (2000). The effects of school climate on school disorder. Annals of the American Academy of Political and Social Science, 567(1), 88-107. file:///C:/Users/demet/ Downloads/welshannals2000.pdf

Yıldırım, A. \& Şimşek, H. (2005). Sosyal Bilimlerde Nitel Araştırma Yöntemleri. Ankara: Seçkin.

Yin, R. K. (1994). Case Study Research: Design and Methods. 2nd edition. Thousand Oaks, CA: Sage. 